\title{
Retraction Note: The a7 nicotinic acetylcholine receptor agonist GTS-21 improves bacterial clearance in mice by restoring hyperoxia-compromised macrophage function
}

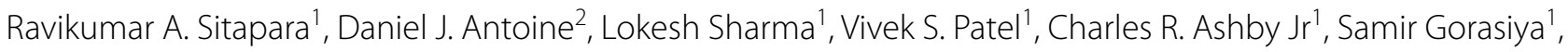
Huan Yang ${ }^{3}$, Michelle Zur ${ }^{1}$ and Lin L. Mantell ${ }^{1,4,5^{*}}$

\section{Retraction Note to: \\ Mol Med (2014) 20:238-247 \\ https://doi.org/10.2119/molmed.2013.00086}

The Editors-in-Chief have retracted this article (Sitapara et al. 2014) following an investigation by the University of Liverpool. The investigation concluded that the mass spectra data contained in Fig. 4 demonstrate evidence of data manipulation, duplicate publication and figure fabrication and are thus unreliable. The mass spectra published in Fig. 4c are identical to mass-spectra published in Supplementary Fig. 2 from another publication (Wang et al. (2015)) and Fig. 3c in (Entezari et al. (2014)). In addition to this, there are inconsistencies between mass stated on the spectral peaks and the $\mathrm{m} / \mathrm{z}(\mathrm{Da})$ value on the $\mathrm{x}$-axis. There is also further possible figure duplication with some adjustment to the size of the peaks and labels. There is obvious similarity between spectra published in Fig. 4b in (Sitapara et al. 2014) and the spectra published in Fig. 3c in (Ju et al. 2014), with some alterations in peak size and mass labelling. There is further circumstantial evidence of research misconduct through inconsistencies in data produced by specific mass-spectrometers

The original article can be found online at https://doi.org/10.2119/molme d.2013.00086.

*Correspondence: Imantell@nshs.edu

${ }^{1}$ Department of Pharmaceutical Sciences, St. John's University College

of Pharmacy and Allied Health Professions, Health Sciences, 128 St. Albert Hall, 8000 Utopia Parkway, Queens, NY 11439, USA

Full list of author information is available at the end of the article as detailed in the figure. The co-authors of the article were found by the investigation not to be complicit in any research misconduct, and they have been invited to resubmit a revised version of the manuscript for further peer review. More information on the university's investigation can be found on the university website (Further update on research misconduct investigation 2020).

All authors agree to this retraction.

\begin{abstract}
Author details
${ }^{1}$ Department of Pharmaceutical Sciences, St. John's University College of Pharmacy and Allied Health Professions, Health Sciences, 128 St. Albert Hall, 8000 Utopia Parkway, Queens, NY 11439, USA. ${ }^{2}$ Medical Research Council Centre for Drug Safety Science, Department of Molecular and Clinical Pharmacology, University of Liverpool, Liverpool, UK. ${ }^{3}$ Laboratory of Biomedical Science, Feinstein Institute for Medical Research, North Shore-LIJ Health System, Manhasset, NY, USA. ${ }^{4}$ Center for Inflammation and Immunology, Feinstein Institute for Medical Research, North Shore-LIJ Health System, Manhasset, NY, USA. ${ }^{5}$ Center for Heart and Lung Research, Feinstein Institute for Medical Research, North Shore-LIJ Health System, Manhasset, NY, USA.
\end{abstract}

Published online: 30 December 2020
References
Entezari M, Javdan M, Antoine DJ, Morrow DM, Sitapara RA, Patel V, Wang M, Sharma L, Gorasiya S, Zur M, Wu W. Inhibition of extracellular HMGB1 attenuates hyperoxia-induced inflammatory acute lung injury. Redox Biol. 2014;2:314-22. https://doi.org/10.1016/j.redox.2014.01.013.
Ju Z, Chavan SS, Antoine DJ, Dancho M, Tsaava T, Li J, Lu B, Levine YA, Stiegler A, Tamari Y, Al-Abed Y. Sequestering HMGB1 via DNA-conjugated beads ameliorates murine colitis. PLoS ONE. 2014;9:8. https://doi.org/10.1371/ journal.pone.0103992.

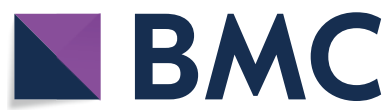

(c) The Author(s) 2020. This article is licensed under a Creative Commons Attribution 4.0 International License, which permits use, sharing, adaptation, distribution and reproduction in any medium or format, as long as you give appropriate credit to the original author(s) and the source, provide a link to the Creative Commons licence, and indicate if changes were made. The images or other third party material in this article are included in the article's Creative Commons licence, unless indicated otherwise in a credit line to the material. If material is not included in the article's Creative Commons licence and your intended use is not permitted by statutory regulation or exceeds the permitted use, you will need to obtain permission directly from the copyright holder. To view a copy of this licence, visit http://creativecommons.org/licenses/by/4.0/. 
Further update on research misconduct investigation, 17 August 2020. https ://news.liverpool.ac.uk/2020/08/17/further-update-on-research-misco nduct-investigation/

Sitapara RA, Antoine DJ, Sharma L, Patel VS, Ashby CR, Gorasiya S, Yang H, Zur $\mathrm{M}$, Mantell LL. The a7 nicotinic acetylcholine receptor agonist GTS-21 improves bacterial clearance in mice by restoring hyperoxia-compromised macrophage function. Mol Med. 2014;20:238-47. https://doi. org/10.2119/molmed.2013.00086.

Wang M, Gorasiya S, Antoine DJ, Sitapara RA, Wu W, Sharma L, Yang H, Ashby CR, Vasudevan D, Zur M, Thomas DD. The compromise of macrophage functions by hyperoxia is attenuated by ethacrynic acid via inhibition of NF-kB-mediated release of high-mobility group box-1. Am J Respir Cell Mol Biol. 2015;52(2):171-82. https://doi.org/10.1165/rcmb.2013-05440C.

\section{Publisher's Note}

Springer Nature remains neutral with regard to jurisdictional claims in published maps and institutional affiliations. 